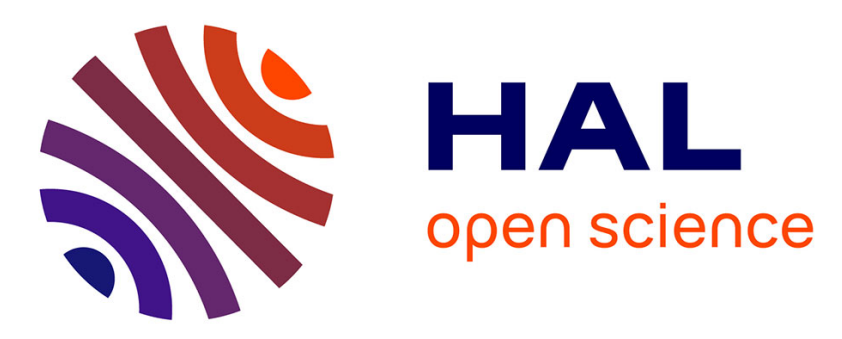

\title{
Brazilian Coffee Export Network: An Analysis Using SNA
}

\author{
Paula Cruz Correia, João Reis, Aguinaldo Souza, Ataíde Pereira Cardoso
}

\section{To cite this version:}

Paula Cruz Correia, João Reis, Aguinaldo Souza, Ataíde Pereira Cardoso. Brazilian Coffee Export Network: An Analysis Using SNA. IFIP International Conference on Advances in Production Management Systems (APMS), Sep 2019, Austin, TX, United States. pp.142-147, 10.1007/978-3-03030000-5_19. hal-02419207

\section{HAL Id: hal-02419207 \\ https://hal.inria.fr/hal-02419207}

Submitted on 19 Dec 2019

HAL is a multi-disciplinary open access archive for the deposit and dissemination of scientific research documents, whether they are published or not. The documents may come from teaching and research institutions in France or abroad, or from public or private research centers.
L'archive ouverte pluridisciplinaire HAL, est destinée au dépôt et à la diffusion de documents scientifiques de niveau recherche, publiés ou non, émanant des établissements d'enseignement et de recherche français ou étrangers, des laboratoires publics ou privés.

\section{(c)(1)}

Distributed under a Creative Commons Attribution| 4.0 International License 


\title{
Brazilian Coffee Export Network: An Analysis using SNA
}

\author{
Paula F. da Cruz Correia1[0000-0003-1648-0398], João Gilberto M. dos \\ Reis $^{1,3[0000-0001-6409-2299], ~ A g u i n a l d o ~ E . ~ d e ~ S o u z a 1,2[0000-0001-6100-752 X], ~ a n d ~}$ \\ Ataíde Pereira Cardoso Jr ${ }^{1[0000-0001-7754-0513]}$ \\ 1 Paulista University - UNIP, PPGEP, São Paulo, Brazil \\ 2 UNIBR, São Vicente, Brazil \\ 3 UFGD, PPGA, Dourados, Brazil
}

\begin{abstract}
Coffee is the most widely consumed beverage in the world, Brazil being its largest producer and exporter. The present study aims to identify the Brazilian coffee trade regarding import markets, main routes, volumes, and main grower states. The proposed methodology adopts a social network analysis approach using the software UCINET 6.0 and Netdraw 2,166 (C). A graphical network is developed to analyze the coffee flow among countries. Besides, the degree of centrality is measured using a matrix that considers 1 or zero. Our results show that Minas Gerais, São Paulo and Espírito Santo have more influence on the network and degree of centrality, inducing the fact that they export to several countries. Germany, United States, Italy, and Japan represent the most important markets. Finally, we conclude that Germany is the leading Brazilian partner with $21 \%$ of country coffee export and the most important player of the supply chain.
\end{abstract}

Keywords: Coffee, Brazilian Production, International Trade

\section{Introduction}

Coffee is one of the most consumed beverages globally. The 2018/19 year crop world coffee production is foreseen as 174.5 million bags of $60 \mathrm{~kg}[1,2]$. Brazil is the largest producer and exporter of coffee and second largest consumer in the world [3,4]. In 2018, the country produced 61,200 thousand bags [5].

With favorable climate and abundant rainfall, Brazil offers an ideal place for the development of this type of plantation. However, Brazilian coffee is mostly exported as green coffee with low added value $[6,7]$.

Currently, two species of grains were cultivated in the country: Coffea arabica and Coffea canephora. The arabica grain is used in high-quality blends, while the other species, known as robust or conilon, is used in the preparation of soluble coffee $[3,4]$.

Brazil has a forecast of 61.7 million bags in the crop year of 2018/19, which means the country will continue as the world leader [8]. Based on this prediction, the importance of Brazil in the coffee exports market is evident. Thus, a rise of $32 \%$ in its production is expected [4]. 
Given this scenario, it is essential to understand the coffee supply chain and investigate how trade works among countries. This overview is interesting not only for Brazil but also for countries and consumers connected to the Brazilian coffee supply chain.

Therefore, this study aims to identify the Brazilian coffee export network and main routes, volumes, and main grower states. The idea is to understand the flows identifying the importance of Brazilian hinterland for coffee exportation. To this end, we perform a social network analysis (SNA) using UCINET 6.0 Cand Netdraw 2,166 @ .

\section{Methodology}

As outlined in the Introduction, we aim to investigate the relations and flows of the Brazilian coffee supply chain. For this purpose, we conduct the follow steps:

- In the first step we collected the volumes of production coffee in order to identify the import countries and regions in Brazil responsible for exports. The data were collected from the COMEX STAT system of the Brazilian Ministry of Development, Industry and Foreign Trade (MDIC) [9], and the International Coffee Organization (ICO)[8].

- After, we processed them using Microsoft Excel in a relational matrix. The relations between import countries and Brazilian regions were established in two-fold: (1) considering the volume of exports in 2018 and (2) indicating the number 1 when a connection exists and 0 otherwise.

- The analysis considered the relations among Brazilian states and import countries in volume of coffee exported plotting a graphical network using Netdraw 2,166 @ [10], and

- Eventually, the degree centrality was performed with matrix 1 and 0 using UCINET 6.0 @ [10].The degree specifies how many nodes were connected to a specific node, known for a "popularity" of a node (actor), divided into two dimensions: in-degree and out-degree [11].

\section{Results and Discussion}

As mentioned earlier, the relations among coffee-producing Brazilian states and import countries were studied using UCINET 6.0 ○and Netdraw 2,166 @ . Figure 1 shows the network plotted considering the number of relations and volume of exports.

Fig. 1 shows that Minas Gerais, São Paulo, and Espírito Santo have more influence on the network centrality degree, because they export for several countries, as can be seen by the node size. Regarding the importers, Germany, United States, Italy, and Japan were highlighted with the major volume represented for the strength of lines. 


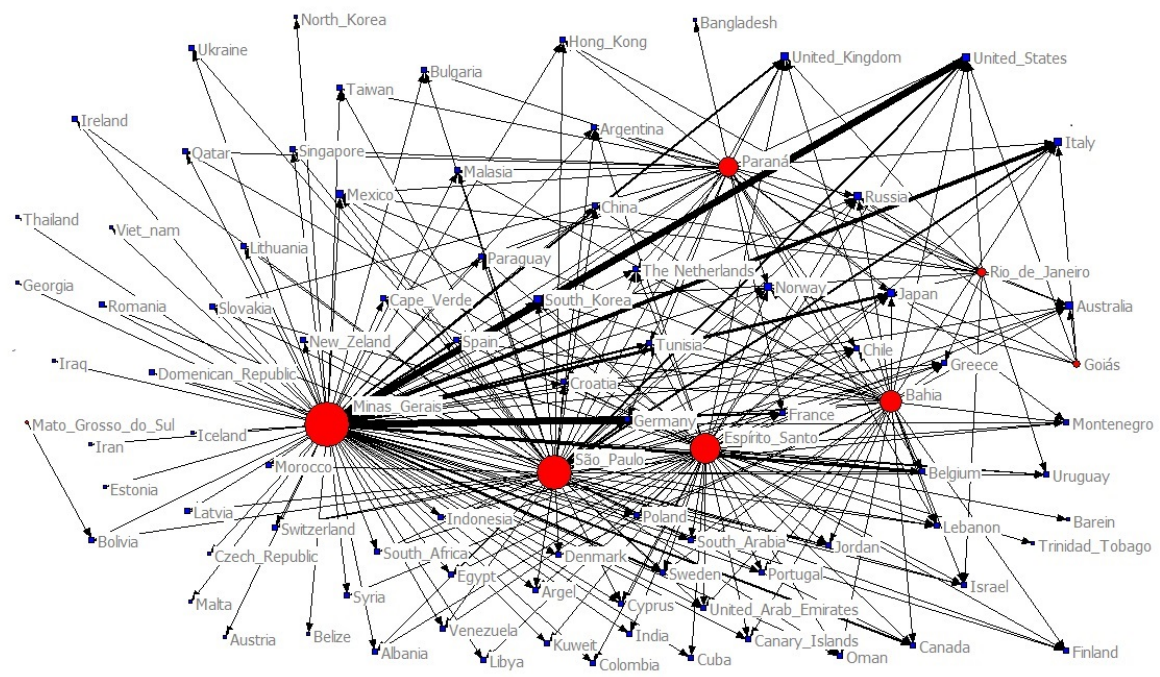

Fig. 1: Brazilian Coffee Exports Network

Coffee production is of great importance for developing countries. For many of them, coffee production is essential to structure their economies, although it still remains a commodity.

With the impositions of consumers, who aspire to increasingly specific characteristics and ecologically correct values, coffee is gaining the status of "specialty" $[12,13]$.

Minas Gerais, São Paulo, and Espírito Santo stand out as the largest producers of the grain in Brazil, and such volume can be attributed to the topographic and climatic characteristics of these states, which provide high-quality plantations [3].

Brazil has a favorable climate with different reliefs, which results in special characteristics for cultivation. In addition, a large amount of rainfall collaborates, making the country a producer of various grain qualities that were used for the production of blends $[3,4,8]$.

Regarding the export of these grains, Brazil maintains a straight relation with the World Trade Organization (WTO) and is expected to continue being the world leader in coffee exportation, with a stake of around $32 \%[8,4,14]$.

The largest coffee importer is Germany, with $34 \%$ stake. It is an important hub of trade in Europe, playing an important role in the reexports of the grain, grounded in its logistical capacity. With a share of $53 \%$ of the EU market, it is considered the largest reexporter. The country is still responsible for about $20 \%$ of the grain consumption in Europe $[15,16]$.

Germany is considered the largest European reexporter of green grains, followed by roasted and last soluble grains. Due to its diverse network of imports, 
the country can produce blends that are pleasing to the most demanding customers [17].

\subsection{Degree of Centrality}

An important measure for calculating the role of an actor in a network is centrality degree. As mentioned, we attempt to identify this degree by using numerical measures. Germany, for example, presented a low centrality degree in comparison with Minas Gerais due to its network, which reflects all relations.

Centrality degree demonstrates which actors are at the center of the relations [1]. It can be illustrated in two ways: outdegree, which measures relations from an export viewpoint - Table 1, and indegree, which measures relations from import perspective - Table 2.

Table 1: Relation of Brazilian coffee-exporting states

\begin{tabular}{lccrr}
\hline \multicolumn{1}{c}{ Country } & \multicolumn{2}{c}{ Outdegree Nrm Outdegree } & \multicolumn{1}{c}{ Volume } & \% Volume \\
\hline Minas Gerais & 79.000 & 0.888 & 20435673.000 & 0.816 \\
São Paulo & 59.000 & 0.663 & 2592659.000 & 0.103 \\
Espírito Santo & 52.000 & 0.067 & 1481201.000 & 0.059 \\
Bahia & 34.000 & 0.382 & 288808.000 & 0.115 \\
Paraná & 30.000 & 0.337 & 178248.000 & 0.007 \\
Rio de Janeiro & 13.000 & 0.146 & 25755.000 & 0.001 \\
Goiás & 6.000 & 0.067 & 16888.000 & 0.0006 \\
Mato Grosso do Sul & 1.000 & 0.011 & 263.000 & 0.00001 \\
\hline
\end{tabular}

Source: Adapt from COMEX STAT [9].

Table 2: Relations among Brazilian coffee-importing countries

\begin{tabular}{lcccc}
\hline \multicolumn{1}{c}{ Country } & \multicolumn{2}{c}{ Indegree Nrm Indegree } & Volume & \% Volume \\
\hline Germany & 5.000 & 0.056 & 309670080.000 & 0.214 \\
United_States & 7.000 & 0.079 & 304009696.000 & 0.210 \\
Italy & 6.000 & 0.067 & 155597344.000 & 0.107 \\
Japan & 7.000 & 0.079 & 101587232.000 & 0.070 \\
Belgium & 5.000 & 0.056 & 94607536.000 & 0.065 \\
Canada & 4.000 & 0.045 & 39715872.000 & 0.027 \\
France & 1.000 & 0.011 & 39548240.000 & 0.027 \\
Spain & 5.000 & 0.056 & 33496540.000 & 0.023 \\
Sweden & 4.000 & 0.045 & 32974272.000 & 0.022 \\
United_Kingdom & 6.000 & 0.067 & 27135916.000 & 0.018 \\
\hline
\end{tabular}

Source: Adapt from COMEX STAT [9].

As seen in Table 1, Minas Gerais is the most important node, sending coffee to $89 \%$ of the countries of the network and representing $82 \%$ of the movements. The results confirm the role of Minas Gerais in Brazil's coffee exports. 
In Brazilian history, São Paulo was a coffee producer and Minas Gerais was milk producer. They were so important at the beginning of the last century that they were used to influence the Presidential elections during the first republic period when candidates of both states altered in power [18]. At present, coffee production migrates to Minas Gerais to take advantage of the mountain regions and adequate climate for production [3][4].

Table 2 demonstrates that Germany, United States, Japan, and Italy are the most relevant importers. While the US and Japan consume a large amount of coffee, Germany and Italy, beyond the consumption, run some coffee blends.

Germany is a real case of success, with a huge and efficient logistics infrastructure linked with an ability to produce a peerless coffee blend. They buy large amounts of green-coffee for processing, industrialization, and resale all over Europe.

Given this situation, we can infer that Brazil and the most part of the producers do not have technology and knowhow for grain processing and end up selling their product as a commodity, allowing the roasting industry to gain huge profit in the sale of the grains [6].

The World Intellectual Property Organization reported in 2017[5] that the producer sells $1 \mathrm{lb}$ of grain for US $\$ 1.25$ for the exporter, which passes to the industry at US $\$ 1.45$. The roasting machines negotiate the final product on average for US $\$ 4.11$.

\section{Conclusions and Outlook}

The main conclusion of our study is that Minas Gerais represents an essential node in the Brazilian coffee international trade. Using the SNA metric, we identify that the state is related with $89 \%$ of importer countries and responds for $82 \%$ of Brazilian coffee exports in 2018. This result shows the necessity of further investigation of coffee plantation and export process in this state.

Another striking conclusion is that Germany is the main Brazilian market with $21 \%$ participation and buying from the five producer states. However, the main purpose is not only to consume but to add value and revenue using their logistics and infrastructure and developing blends.

Therefore, the Brazilian coffee export network is part of a complex supply chain that involves many countries and provides value to customers. Our conclusions indicate that further analysis is necessary for revealing how this network operates.

Finally, the contribution of this study has been to confirm the need to explore a new scientific understanding about a network little explored from the viewpoint of trade and logistics.

\section{Acknowledgements}

This study was financed in part by the Coordenacão de Aperfeicoamento de Pessoal de Nível Superior “Brasil (CAPES)” Finance Code 001. 
Correia et al.

\section{References}

1. United States Department of Agriculture: https://apps.fas.usda.gov/ psdonline/circulars/coffee.pdf

2. Ponte, S.: The 'Latte Revolution'? Regulation, Markets and Consumption in the Global Coffee Chain. World Development 30(7), 1099-1122 (2002), http:// linkinghub.elsevier.com/retrieve/pi i/S0305750X02000323

3. Ministry of Agriculture, Livestock, and Food Supply: http://www.agricultura . gov.br/assuntos/politica-agricola/cafe/cafeicultura-brasileira

4. Brazilian Coffee Exporters Council: https://www.cecafe.com.br/publicacoes/ fatia-do-brasil-nas-exportacoes-globais-de-cafe-deve-aumentar-20190116/

5. International Coffee Organization: http://www. ico.org/prices/po-production. pdf

6. World Intellectual Property Report: https://www.wipo.int/publications/en/ details. jsp?id=4225

7. Lderach, P., Oberthr, T., Cook, S., Estrada Iza, M., Pohlan, J.A., Fisher, M., Rosales Lechuga, R.: Systematic agronomic farm management for improved coffee quality. Field Crops Research 120(3), 321-329 (2011), https: / / linkinghub . elsevier . com/retrieve/pii/S0378429010002613

8. ICO International Coffee Organization: http: / / www . ico.org/

9. Ministry of Agriculture, Livestock, and Food Supply: http://comexstat.mdic. gov.br/pt/home

10. Alejandro, V., Norman, A.: Manual Introdutrio Anlise de Redes Sociais. Universidad Autonoma Del Estado de Mexico (2005)

11. Aloini, D., Benevento, E., Stefanini, A., Zerbino, P.: Process fragmentation and port performance: Merging SNA and text mining. International Journal of Information Management p. S0268401219300040 (2019), https: / / linkinghub . elsevier.

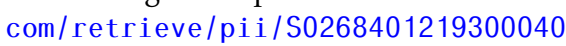

12. Sindicato da Indústrias de Café de Minas Gerais: http://sindicafe-mg.com.br/ cafe-no-mundo

13. Vicol, M., Neilson, J., Hartatri, D.F.S., Cooper, P.: Upgrading for whom? Relationship coffee, value chain interventions and rural development in Indonesia. World Development 110, 26-37 (2018), https://1inkinghub.elsevier.com/retrieve/ pi i/S0305750X18301682

14. Guerise, L.C., Silva, C., Rossi, C., Vilarinho, L.: A Logística Integrada na Exportao de Café pelo Porto de Santos. O Estudo das Cadeias de Brasileiras de Café. In: Inovação Tecnológica e Propriedade Intelectual: Desafios da Engenharia de Produção na Consolidação do Brasil no Cenário Econômico Mundial. p. 13. ABEPRO, Belo Horizonte (2011)

15. Centre for the Promotion of Imports from Developing Countries: https://www . cbi.eu/market-information/coffee/germany

16. Centre for the Promotion of Imports from Developing ]countries: https://www . cbi.eu/market-information/coffee/trade-statistics/

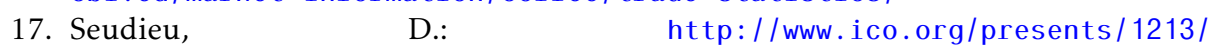
icc-110-4-reexports-germany.pdf

18. Negro, A.L., Brito, J.: A Primeira República muito além do café com leite. Topoi (Rio de Janeiro) 14(26), 197-201 (Jun 2013) 